\title{
The Floating Ampersand: STS Past and STS to Come
}

\author{
SHEILA JASANOFF \\ HARVARD UNIVERSITY
}

\begin{abstract}
STS has become a discipline in the sense that it offers new ways to read and make sense of the world. It remains an amalgam, however, of two linked yet separate lines of inquiry, both abbreviated as STS. Science and technology studies refers to the investigation of S\&T as social institutions; science, technology and society, by contrast, analyzes the external relations of S\&T with other institutions, such as law or politics. This essay reflects on the implications of this ambiguity for institutionalizing STS as a field of its own, drawing on the author's experiences in building STS at two universities.
\end{abstract}

\section{Keywords}

science and technology studies; institutionalization; disciplines; interdisciplinarity

\section{Introduction}

Human beings are given to redescribing their world. The greatest achievements of human creativity-in art, in literature, and in the sciences-come from just that urge to reread and rewrite experience. My own history of working in and helping to shape Science and Technology Studies (STS) has long been an exercise in rereading and rewriting texts, contexts, and practicesan experience marked and bracketed by what I call here "the floating ampersand," that is, the "and" that connects the three letters in the abbreviation STS. This is a brief, very personal account of the development of STS as I have observed and participated in it for an academic lifetime, in more or less close conversation with sociologists. I hope to convey a sense of what I see as important in STS's emergence, and how the field as I know it relates to the ways of exploring science, technology, and knowledge that shelter comfortably under SKAT's big tent.

'Sheila Jasanoff, Email: sheila_jasanoff@harvard.edu

Copyright (C) 2016 (Sheila Jasanoff). Licensed under the Creative Commons Attribution Non-commercial No Derivatives (by-nc-nd). Available at estsjournal.org. 


\title{
Sightlines
}

The arts have routinely drawn inspiration from new sightlines that turn the familiar world into a place of mystery or spectacle. In October 1816, the twenty-one-year-old John Keats sat with his friend Charles Cowden Clarke and read with growing excitement George Chapman's seventeenth century translation of Homer's Odyssey. Before that encounter, Keats must have known Homer only through Alexander Pope's 1726 translation. The two versions were markedly unlike: Pope's regular and rhythmic, in rhymed couplets; Chapman's harsher, more dramatic, and more visual. The passage that gripped Keats, in Clarke's recollection, explains the young poet's reaction. In Book V, Odysseus is cast ashore after a storm. Pope says:

\footnotetext{
That moment, fainting as he touch'd the shore, He dropp'd his sinewy arms: his knees no more Perform'd their office, or his weight upheld:

His swoln heart heaved; his bloated body swell'd:

From mouth and nose the briny torrent ran;

And lost in lassitude lay all the man,

Deprived of voice, of motion, and of breath;

The soul scarce waking in the arms of death.
}

Chapman renders the same scene so:

\begin{abstract}
Then forth he came, his both knees falt'ring, both His strong hands hanging down, and all with froth His cheeks and nostrils flowing, voice and breath Spent to all use, and down he sunk to death.

The sea had soak'd his heart through; all his veins His toils had rack'd t'a labouring woman's pains.

Dead weary was he.
\end{abstract}

We know from Clarke's account that Keats was especially struck by the line, "The sea had soak'd his heart through," for which there is apparently no basis in the original text. And yet this reading, in its monosyllabic directness and stark, emotive appeal, fired Keats to his own act of creation. The very next morning he sent his friend a sonnet that found its way into the canon of English literature, On First Looking into Chapman's Homer. From its immortal opening line, "Much have I travell'd in the realms of gold," the sonnet offered its own magical, fourteen-line remix of science, music, and travel fantasy. Chapman's Homer is largely lost to modern readers, but in Keats' sonnet the echoes of the old translation remain and breathe.

For Keats, a radical rereading of a familiar text was a spur to poetic invention. For social scientists, too, new readings of the human condition open up remarkable possibilities for understanding, explanation and critique, most especially perhaps when the readings come from 
outside the comfort zones of the theory-bound safe enclaves of disciplinary normal science. The theme for this collection- "Positioning the Field: STS Futures"-invites us to celebrate one such new way of reading and looking, a way that, in its turn, has provided the scaffolding for a disciplined scholarly tradition. That lens is STS.

It is not entirely far-fetched to liken STS's readings of the world to Chapman's reading of Odysseus cast ashore. There is across all of STS the same eschewing of given-in-advance tradition (for example, Pope's heroic couplets), the same minute attention to observed phenomena ("froth" on cheek and nostrils, not Pope's more literary "briny torrents"), even a textually unwarranted grant of agency to a non-human thing (the sea). Through close observation, STS perspectives have revealed unexpected openness and plasticity in the world we inhabit, in which we form our selves and organize our collectives, and which we continually remake with the products of our dexterity and experimentation. STS at its best is a key that makes black boxes spring open (Bijker et al. 1987), brings into view the intricate interplay of nature and culture (Latour 1987), and reveals the hidden intertwining of knowledge, identity, and norms (Jasanoff 2004).

Setting STS beside older and still current sociologies of knowledge, moreover, demonstrates why disciplinary speciation is never a zero sum game. The arrival of the new augments the old but does not lessen it. Feminism, postcolonialism and subaltern studies taught us new ways to think about power and its evolution from neglected sociopolitical points of view. They did not negate Marx's theories of labor and capital, nor Durkheim's understandings of social norms, nor Weber's insights into bureaucracy. A similar expansion of intellectual horizons, permitting new questions to be asked and new interpretive frameworks to be developed, has been my experience in STS. Doing STS does not, for me, deny the role of social groups, political movements, or cultural communities; it does enable new ways of querying how knowledge and belief are constructed, proof and evidence validated, meaning conferred on inanimate things, and material objects made to function in harmony with human bodies and collectives. Put differently, STS provides a distinctive gaze on modernity, and it does so by problematizing the productions of science (or, more broadly, knowledge) and technology in ways that complement the work of other disciplines without diminishing their contributions to social theory.

\section{Science and Society: Bridging the Gap}

STS's position in the social sciences today reflects its own complex and multiple origins in the interstices of anthropology, history, sociology, and politics-and, of course, science and technology (S\&T). In the United States, politics came first. Despite the first " $\mathrm{s}$ " of the abbreviation, American STS at first had relatively little to do with science as such. Pedagogically, the evolution of scientific ideas had already been committed to history of science, a specialty that took shape after World War II and was, by the 1960s, installed in many American universities as a special field within history departments or, in some cases, as a department of its own.2 As captured in the popular survey course title "from Plato to NATO," history of science offered

${ }^{2}$ Notable examples include Harvard, Wisconsin, and the University of Cambridge (UK). 
students a relatively straightforward tale of progressive enlightenment, in which quixotic and partial ideas ceded ground over time, or sometimes achieved added solidity, ${ }^{3}$ by accommodating the results of ongoing experiment and observation. As the history of science matured, its storytelling grew more complex, exploring how ideas and modes of inquiry are embedded in social and cultural contexts. Practitioners began speaking of a transition from internalist to social histories of science. But the origin and transmission of scientific beliefs and practices remained central to the field, and to a large extent still are its primary concerns. ${ }^{\star}$ STS, by contrast, queried the relationship between the texts of science and their sociopolitical contexts with significantly different objectives. STS sought to trace not only how ideas and their applications change but, importantly and symmetrically, how those changes transform the worlds out of which they originate and in which they have effects.

Historically, STS came to stand for two quite different things, distinguished by the position of the word "and": both "science, technology and society" and "science and technology studies." That ambiguity initially helped STS to become a recognized field, accepted by many natural scientists and engineers, although it may have hurt STS's longer-term institutionalization within contemporary research universities. But before turning to STS's prospects in this century it would help to recall some salient aspects of the field's evolution in the preceding fifty years.

American universities, to begin with, embraced the version of STS that puts the "and" between the T and the second S that stands for society. The aim of STS, so conceived, was to make explicit how the pursuit of S\&T affects society and social order. Pressing public concerns of the time challenged any straightforward equating of progress with advances in science and technology. Many troublesome things were going on in the world, compromising humanity's safety and well-being, and most were connected in one way or another to scientific and technological developments. This was the decade of Rachel Carson, Vietnam and Napalm, the Cuban missile crisis, the space race, the Apollo missions, and eventually the moon landing. The Cold War was at its height, with the looming threat of nuclear catastrophe. It was also the first decade of postwar feminism, along with (in the United States) antiwar and civil rights activism, as well as the rise of a new American environmentalism to fight the destructive effects of human habitation on Earth. Climate change was not yet on the horizon, let alone the discourse of the anthropocene, but more immediate hazards were: choking air, rivers on fire, pesticides in human breast milk, nuclear power plants generating unmanageable radioactive wastes, and the sprawl

${ }^{3}$ Famous cases of theories solidifying over time include plate tectonics, explaining continental drift, and the theory of evolution. A recent example of this way of narrating scientific history is the detection of gravitational waves in early 2016. Dennis Overbye writes: "More generally, it means that a century of innovation, testing, questioning and plain hard work after Einstein imagined it on paper, scientists have finally tapped into the deepest register of physical reality, where the weirdest and wildest implications of Einstein's universe become manifest." Overbye, "Gravitational Waves Detected, Confirming Einstein's Theory," New York Times, February 11, 2016. STS scholars might have been inclined to tap more deeply into the register of "plain hard work."

" One disciplinary practice underscores this tendency: appointments in history of science are still defined largely in terms of particular scientific disciplines (e.g., physics, biology, medicine) and their location within specific historical periods, usually a century. STS by contrast is more eclectic, embracing more complex topics, such as innovation, as well as theoretical perspectives, geographical regions, and social transformations. STS-trained Ph.D.'s correspondingly find jobs in many fields, including but not limited to sociology. 
of cement and cars, malls and runways into formerly green areas, where loss of birdsong was not the only calamity that made people afraid.

Accepting the crucial role of S\&T in modern life-indeed scientists and engineers were among the first to endorse the need for STS-early STS research often sought to combat alliances between S\&T and regressive forces in society. Academic programs were formed to raise students' awareness of the need for greater responsibility in the uses and applications of science. Important among these was the Program on Science, Technology and Society at Cornell University, founded in 1969 by three prominent scientists and a philosopher. Curiously, a program focusing on science's social implications initially failed to attract the attention of social scientists. My own career in STS began in that program, almost a decade after its formation, in 1978.

At Cornell, as elsewhere in America, STS was not especially concerned with the rise or spread of scientific ideas, the nature of scientific practices, or the construction of truth claims within science. Instead, it focused almost exclusively on the politics of technology, thereby unconsciously reinscribing the classic narrative of impure motives of power and dominance corrupting the purity of science. One strand of that story concerned the forces of industrialization and militarization that pull science away from the Mertonian virtues of disinterestedness and communalism (Merton 1973; also Winner 1986). Another focused more on heedlessness and hubris in the applications of science, especially on the part of profit-hungry corporations that failed to acknowledge uncertainty and risk in connection with technologies such as nuclear power, agricultural chemicals, pharmaceuticals, and eventually biotechnologies. A strong subtext was the need for scientists and citizens to become more vigilant about the bending of science to serve malign purposes. Prominent scientists lent their prestige to this endeavor. At Cornell, Hans Bethe, a Nobel Laureate and hallowed figure in the university's postwar constellation of eminent physicists, strongly advocated for nuclear arms control, although he also firmly supported the development of nuclear power. The chemist Franklin Long, chief architect of Cornell's STS Program, shared Bethe's passion for disarmament. Long's legacies included not just STS but also the Peace Studies Program, later named for his protégée Judith Reppy.

Reflecting these and other normative orientations, American STS of the 1970s and 1980s was broadly configured as a space for research and teaching to illuminate the social and political implications of society's technological choices and thereby improve the politics of technical decisions. At Cornell, Dorothy Nelkin, hired by the STS Program's founders to investigate problems they themselves had little time to explore, pioneered a genre of research that took social conflicts as its main site of investigation and case studies as its chief methodology. In a series of edited volumes called simply Controversy, Nelkin pulled together studies of major American technological disputes of the moment. The first collection, published in 1979, included chapters on nuclear waste disposal, air bags, vinyl chloride in the workplace, fetal research, and Creation versus evolution in the schools (Nelkin 1979). Only the last focused on science, not technology.

The term "interpretive flexibility" was not yet current in American STS talk, but awareness of it featured centrally in STS case studies, since actors in each story assigned different readings to the same observations. Case after case documented that where one stands in society affects what one sees of the world during a controversy, and that those with more power to shape 
the dominant sightlines typically win the day. These were examples of a weak social constructivism, not questioning a common background reality, but suggesting that social identities and affiliations determine how facts are constituted in public domains. Not surprisingly, given the explanatory power accorded to social categories, the contributors to Nelkin's controversy volumes included many sociologists. Early in my involvement with STS these were the scholars I interacted with most closely. The group included Daryl Chubin, Susan Cozzens, Thomas Gieryn, Edward Hackett, Gerald Markle, and James Petersen, among others. Nelkin herself had never undertaken doctoral study in any field, but she came to be regarded as a sociologist and finished her career as a distinguished professor in that field at New York University.

The epistemological and metaphysical questions that we view today as central to STS were germinating not at Cornell or MIT or Harvard but primarily on the other side of the Atlantic. In Edinburgh, for example, the focus of the Science Studies Unit, inspired by David Bloor's "strong programme" (Bloor 1976), was primarily on science: no need here for any "and," because technology, to start with, was not in the picture at all. Around the same time, Bruno Latour and Steve Woolgar were conducting the ethnographic research that led to Laboratory Life (Latour and Woolgar 1979), the first major STS lab study. These European scholars asked how best to understand the problems that had long preoccupied philosophers about the nature of facts and truth. A sociological method did develop in the Edinburgh School, but this was largely a sociology of scientists engaged in rival projects of knowledge making-not, as in America, a sociology of society's engagement with the migration of science from labs into technologies. Edinburgh case studies, consequently, were as often historical as contemporary (Shapin and Schaffer 1985; Shapin 1994). Even influential works that queried how technologies develop from science (MacKenzie 1990) —or how facts become artifacts (Bijker et al. 1987)—stayed closely attuned to the dynamics of scientific (and later technological) practice, above all the practices of verification, rather than to the practices of other social institutions such as the law that also shape technologies, let alone to the wider movements of power, knowledge, values or imaginaries within society.

Relations between STS and sociology proved harder to negotiate and stabilize than creating something new named STS. At Cornell, the chair of the Sociology Department participated in the first search we ran for a senior position in STS, in 1989. When that search failed, Sociology no longer wished to be involved in a second (successful) one, and efforts to gain a joint appointment for STS's actual hire, Trevor Pinch, initially failed. ${ }^{5}$ The STS Handbook that I co-edited for the Society for Social Studies of Science (4S) (Jasanoff et al. 1995) at about the same time engendered additional frictions between the editorial team and leading figures in American sociology. Open solicitation for prospective authors elicited a list that overwhelmingly favored the newer constructivist approaches over the sociology of knowledge that had been prevalent in

s Many years later Cornell's Sociology Department did offer Pinch a joint appointment, a courtesy not extended to every sociologist in S\&TS. Graduates of the S\&TS Department, however, have been appointed in leading US sociology departments. 
the United States (for possible reasons, see Kuklick 1983), and the older school never quite forgave the upstart field.

Gradually, however, a new intellectual frontier emerged-science and technology studies-signaling with its relocated "and" that the objects under the investigative lens were S\&T in themselves, as institutions and practices deserving analysis by social scientists with all of the methods at their disposal. This STS became the umbrella under which the more academically oriented programs, often those offering graduate degrees or certificates, began grouping themselves by the early 1990s. A non-exhaustive list of US science and technology studies programs includes Brown (undergraduate degree), Cornell, UC Berkeley, UC San Diego and Wisconsin-Madison. Stanford, where STS won new popularity with the increasing economic clout of Silicon Valley, retained the name "science, technology and society" for its undergraduate major. MIT's program, which also keeps that name, offers a doctoral degree (HASTS) that combines history and anthropology with STS.

At Cornell, it was the birth of a new department of Science and Technology Studies in 1991 that triggered a renaming and a formal displacement of the ampersand, in a move that was at once reflexive and political. Merging the precursor programs on STS and the History and Philosophy of S\&T, the department included historians and philosophers who did not wish to identify with a politically inflected STS that they found alien, perhaps alienating. In the timehonored style of American politics, we found a compromise: the newly repositioned "and" was inserted into both the department's abbreviated name (S\&TS) and its logo, which initially consisted of STS written in bold letters across a large, greyed-out ampersand in the background. But the more important feature of the compromise was a tacit recognition that S\&TS faculty were held together more by the subject matter they studied than how exactly they chose to study it.

Symbolic action helped to weld together a faculty at Cornell that at first had little in common but eventually came together harmoniously to work on the routines of academic life, from grant applications to designing a new core curriculum for Ph.D. students. It helped, no doubt, that several members of the department had already collaborated on a major training grant from the National Science Foundation that provided the impetus for the department's creation. For several of us, however, the adventure of the floating ampersand prompted its own deeper reflection on the connections between S\&T and society and eventually pointed the way toward a stronger conceptual synthesis among varied STS traditions. This was the experience I brought to Harvard when I moved here, and it guided, and still guides, my sense of the challenges and opportunities confronting STS in this new century.

\section{Too Big a Tent?}

The last chapter in this short reflection has been written at Harvard, where I joined the John F. Kennedy School of Government in 1998 and established a new STS Program in 2002. ${ }^{\circ}$ As if winding the clock back, I chose to name this program "science, technology and society" (while

- For an overview of the Harvard STS Program, see http://sts.hks.harvard.edu/. 
retaining "science and technology studies" for my own professorial title). This move was wholly intentional, in order to include in the STS tent the scientists and engineers who, as at Cornell, firmly supported the idea of a field centrally concerned with S\&T's challenges to society. The rubric also embraced colleagues from other fields, including sociology and anthropology, who do not see themselves as doing S\&TS (science and technology studies) but still are deeply interested in ST\&S (science, technology and society). Nearly fifteen years after the Harvard program's foundation, the risks and benefits of the floating ampersand can begin to be assessed, and they speak in some sense to the future of STS as an academic "field of its own" (Jasanoff 2010). I offer a brief evaluation under three headings-inclusiveness, coherence, and impact-before hazarding a few thoughts in conclusion.

Publicly, the STS Program at Harvard capitalized on an inclusive vision of S\&TS that does not insist on disciplinary purity but acknowledges (as SKAT also does) that there are multiple ways to look at the place of S\&T in society. Inclusiveness brings tangible rewards. The program's weekly colloquium series is popular with audiences across Harvard, its public events draw large and varied crowds, and its website and social media presence attract thousands of visitors on a regular basis. The term "STS," virtually unknown when I came to Harvard, now enjoys wide name recognition, and it is a space that many regard as desirable to be seen in.

Yet, visibility and appeal arguably came at the price of intellectual coherence, at least on an institutional level. An STS that offers all things to all people can be left at day's end with few resources to call its own, and none distinctive enough to justify claims for the kind of support and recognition claimed by traditional disciplines (Hilgartner 2003). At Harvard, as of this writing, efforts to build disciplinary coherence through doctoral training, dedicated appointments, and programmatic support have failed to win high-level administrative approval despite increasing demand from below and from the world at large. Too many competing interests are able to claim the territory in which S\&T connect to society only through an ill-defined "and." To the untutored eyes of university cost-cutters it looks as though there are enough places and people engaged in what some administrators loosely label as "science, technology and society studies." Why then bother to invest resources in a space marked STS that is not a discipline?

The answer, of course, goes back to sightlines and the opening up of new perspectives. These are the dimensions on which an STS enterprise standing resolutely outside of disciplinary power structures can achieve, indeed is achieving, impact of a kind that might be the envy of better established fields. It has become clear over the past few decades that STS is a generative place, with spin-offs that matter not only to the social sciences and humanities-important as these are-but also to the work of professionals, policy makers, and citizens who hope to make beneficial changes in the world. In these respects, STS offers some of the creative force of rereading modernity that Keats discovered in, for him, a novel translation of the classics. STS enables people not only to re-represent the world but to intervene in its freshly discovered inner workings. I will close with a reflection on that horizon of promise.

"Leah Yared, "A Forgotten Field? How Science, Technology, and Society is striving for a place in the academic fabric of Harvard," Harvard Crimson, November 18, 2016, http:// www.thecrimson.com/article/2015/11/18/science-technologysociety-feature/. 


\section{Remaking Science, Technology and Society}

A dozen years ago, Stephen Hilgartner (2003) proposed a series of strategic steps to move STS up the gradient of academic institutionalization. Those prescriptions, coming from an eminent sociologist of knowledge and organizations, still stand as a valuable template for anyone interested in the field's wider diffusion through a skilled labor force. One could question the metaphor of a gradient as perhaps too linear, suggesting that there is a single direction ("up") and a straightforward progression from one position to the next on the way to more secure institutionalization. Hilgartner describes three current organizational formats for STS-subfield, interdiscipline, new discipline-that differ from one another in the degree of autonomy granted to STS to develop its own curricula, teach its own canon, and develop its own brand of professional identity within the ecology of existing disciplines. In his telling, these formats represent almost a continuum along which STS, as an "emerging discipline," should seek to progress, although he recognizes that the context for STS will vary across institutions, and that local variability must be respected if attempts to strengthen STS are to succeed. Inserting an undergraduate STS curriculum into a liberal arts college, for example, presents different, perhaps lower, entry barriers than creating a new STS doctoral program at a research university, where disciplines often jealously guard the door against new entrants. My own experiences in building STS at two leading universities, Cornell and Harvard, attest to the lack of any reliable formula for how to make this happen, or even any guarantee that STS will "take" when grafted onto different parent trees.

Nonetheless, Hilgartner's reasons for STS to seek stronger institutional moorings for its own teaching and training efforts remain as compelling as when they were articulated in 2003. The distinctive questions STS scholars ask, the methods they use to advance their inquiries, and the findings from more than a generation of research all need to be imparted systematically in order to grow and develop the field. There is simply no substitute for rigorous academic training and the sense of intellectual identity, authority, and community it confers. Institutional infrastructures are important because they support the thought collectives needed to validate new ways of looking at and describing the world. Professional society sections such as SKAT, or the Science and Democracy Network that I have been privileged to help build, are a necessary component of such infrastructures. Complementing the work of academic departments, these regular meeting points provide invaluable additional spaces in which cross-talk among selfidentified STS scholars, sociologists, and participants from other disciplines can flourish at growing levels of sophistication, to the benefit of all.

But there is a parallel strategy that also needs pursuing, one more consistent with STS's disruptive tendencies as the field that explores the foundations of knowledge and hence makes the expert-dominated structures of modernity less comfortable. This is to take the "and" seriously: not only as an object of sustained critical inquiry but as an instrument to reconnect STS to society-to press into the domains where the designers of the future operate, in law, policy, architecture, engineering, theater, music and the arts, and not least citizen movements. It is to use 
the analytic keys of STS to open up the visions of all the knowledge-workers of the world (and that is a great many of us) to new possibilities for pulling apart the stubborn, material structures of power and putting them back together into constructs as yet unimagined. In my own work, I have used such devices as amicus briefs, cross-disciplinary co-teaching, web-based teaching tools, summer schools, and professional training programs to disseminate STS perspectives to people in worlds of action not constrained by the rigidities of the modern research university. Others more adept with today's digital media will find far more creative ways of intervening, of that I am sure. All one needs is that first baby step into STS, the radical, critical move that asks, "Why is it so, and must it be?" The stakes? Not only are there unsung sonnets locked up in each of us, but epics waiting to be written collectively.

\section{References}

Bijker, W., T. Hughes, and T. Pinch, eds. 1987. The Social Construction of Technological Systems: New Directions in the Sociology and History of Technology. Cambridge, MA: MIT Press.

Bloor, D. 1976. Knowledge and Social Imagery. Chicago: University of Chicago Press.

Hilgartner, S. 2003. "Institutionalizing Science \& Technology Studies in the Academy." In Social Studies of Science and Technology: Looking Back, Ahead, edited by B. Joerges and H. Nowotny, 201-210. Dordrecht: Kluwer.

Jasanoff, S., ed. 2004. States of Knowledge: The Co-Production of Science and Social Order. London: Routledge.

Jasanoff, S. 2010. "A Field of Its Own: The Emergence of Science and Technology Studies." In The Oxford Handbook of Interdisciplinarity, edited by R. Frodeman, J. T. Klein and C. Mitcham, 191-205. Oxford: Oxford University Press.

Jasanoff, S., G. E. Markle, J. C. Petersen, and T. Pinch, eds. 1995. Handbook of Science and Technology Studies. Thousand Oaks, CA: Sage Publications.

Kuklick, H. 1983. "The Sociology of Knowledge: Retrospect and Prospect." Annual Review of Sociology 9: 287-310.

Latour, B. and S. Woolgar. 1979. Laboratory Life: The Social Construction of Scientific Facts. Beverly Hills: Sage Publications.

Latour, B. 1987. Science in Action: How to Follow Scientists and Engineers through Society. Cambridge, MA: Harvard University Press.

MacKenzie, D. 1990. Inventing Accuracy: An Historical Sociology of Nuclear Missile Guidance. Cambridge, MA: MIT Press.

Merton, R. K. 1973. "The Normative Structure of Science." In The Sociology of Science: Theoretical and Empirical Investigations edited by R. K. Merton, 267-278. Chicago: University of Chicago Press.

Nelkin, D., ed. 1979. Controversy: Politics of Technical Decisions. Beverly Hills: Sage.

"For example, see the research platform on "sociotechnical imaginaries,"

http://sts.hks.harvard.edu/research/platforms/imaginaries/. 
Shapin, S. 1994. A Social History of Truth: Civility and Science in 17" Century England. Chicago: University of Chicago Press.

Shapin, S. and S. Schaffer. 1985. Leviathan and the Air-Pump: Hobbes, Boyle, and the Experimental Life. Princeton, NJ: Princeton University Press.

Winner, L. 1986. "Do Artifacts Have Politics." In The Whale and the Reactor: A Search for Limits in an Age of High Technology. Chicago: University of Chicago Press. 